\title{
Why are there so many plant species in the Neotropics?
}

\author{
Alexandre Antonelli ${ }^{1}$ \& Isabel Sanmartín ${ }^{2}$ \\ 1 Gothenburg Botanical Garden, Carl Skottsbergs gata 22A, 41319 Göteborg, Sweden \\ 2 Real Jardín Botánico, CSIC, Plaza de Murillo 2, 28014 Madrid, Spain \\ Authors for correspondence: AlexandreAntonelli, alexandre.antonelli@vgregion andIsabel Sanmartín,isanmartin@rjb.csic.es
}

\begin{abstract}
The Neotropical region (tropical America) is the most species rich region on Earth. Several causes have been proposed to explain this extraordinary biodiversity, which may be very roughly classified into two major categories: 'biotic' (e.g. soil adaptations; biotic interactions with pollinators, dispersers and herbivores; niche conservatism; dispersal ability) and 'abiotic' (e.g. time; rainfall, temperature and area; mountain uplift; hydrological changes). In this paper we review the evidence for each of these postulated causes of diversification and provide general directions towards further testing. We highlight the need of more well-sampled and dated phylogenies and urge increased inter-disciplinary collaboration.
\end{abstract}

Keywords biogeography; botany; evolution; Neotropical biomes; Tropical America

\section{- THE NEOTROPICAL REGION: AN INTRODUCTION}

\author{
In England any person fond of natural history \\ enjoys in his walks a great advantage, \\ by always having something to attract his attention; \\ but in these fertile lands teeming with life, \\ the attractions are so numerous, \\ that he is scarcely able to walk at all. \\ Charles R. Darwin, 19 Apr. 1839, \\ after leaving Brazil on board of HMS Beagle.
}

The word Neotropic (from the Greek neos = "new") refers to the tropical region of the American continent, or "New World" - a term coined by Peter Martyr d'Anghiera in 1493 shortly after Christopher Columbus's first voyage to the Americas (O'Gorman, 1972). As currently defined (Schultz, 2005), the Neotropical ecozone extends from central Mexico in the north to southern Brazil in the south, i.e., including Central America, the Caribbean islands and most of South America.

Geologically, the Neotropics are distributed across three tectonic plates: the North American, the Caribbean and the South American (Fig. 1), each with a very different geological history. The South American and African plates formed part of the giant palaeocontinent of Gondwana for hundreds of millions of years until its final break-up about 100 million years (Ma) ago (Scotese, 2001).

Precipitation and annual mean temperatures are generally high, but there is great regional variation. Whereas western Colombia in South America has amongst the highest precipitation in the world, with almost $9000 \mathrm{~mm}$ annually, other regions are extremely dry. In the Amazon Basin, precipitation ranges between 1500 and $3000 \mathrm{~mm}$ annually, averaging around $2000 \mathrm{~mm}$ in central Amazonia (Salati \& Vose, 1984).

Before human colonisation, the rain forest of Amazonia accounted for about one third of the entire South American continent. There are however several other terrestrial biomes in the Neotropics that are noteworthy for their size and ecological importance, such as the Cerrado and the Atlantic forest of eastern Brazil. The approximate distribution of major Neotropical biomes/ecosystems is given in Fig. 2, and Kricher (1999) provides an accessible overview of their characteristics and biodiversity.

\section{NEOTROPICAL PLANT BIODIVERSITY: PATTERNS AND HYPOTHESES}

Distribution of plant diversity. - Ever since the early voyages of renowned explorers, such as Humboldt (1820), Darwin (1909) and Wallace $(1852,1853)$, the outstanding species richness found today in the Neotropics has remained elusive in our understanding of the evolution of life on Earth. Comprising around 90,000-110,000 species of seed plants, the Neotropics alone harbours about $37 \%$ of the world's species. This is perhaps more than tropical Africa (30,000-35,000 spp.) and tropical Asia and Oceania combined (40,000-82,000 spp.; Gentry, 1982; Thomas, 1999; Govaerts, 2001). Explaining why there are so many species in the Neotropics is also relevant to further our knowledge on the global "latitudinal species gradient" - the fact that species richness tends to be higher at tropical latitudes (Hillebrand, 2004), a pattern that has sparked a long-standing search for ecological and evolutionary explanations (Kozak \& Wiens, 2007; Mittelbach \& al., 2007; Buckley \& al., 2010).

Within the Neotropics, as in any other region, plant species are not distributed evenly. In a seminal paper, Gentry (1982) demonstrated that there are two main patterns of plant distribution, which he termed "Amazonian-centred" and "Andean-centred". Typically, groups that are rich in species in one of these centres are relatively species-poor in the other. We propose to name it "the Gentry pattern".

Andean-centred groups have a centre of diversity in northwestern South America and adjacent Central America. Gentry exemplified this pattern with Maas's (1977) diversity map for the genus Renealmia (Zingiberaceae; Fig. 3). According to 
Fig. 1. The Neotropical region extends from central Mexico in the north to southern Brazil in the south, thus occupying the North American, the Caribbean and the South American tectonic plates. (adapted from Wikimedia Commons).

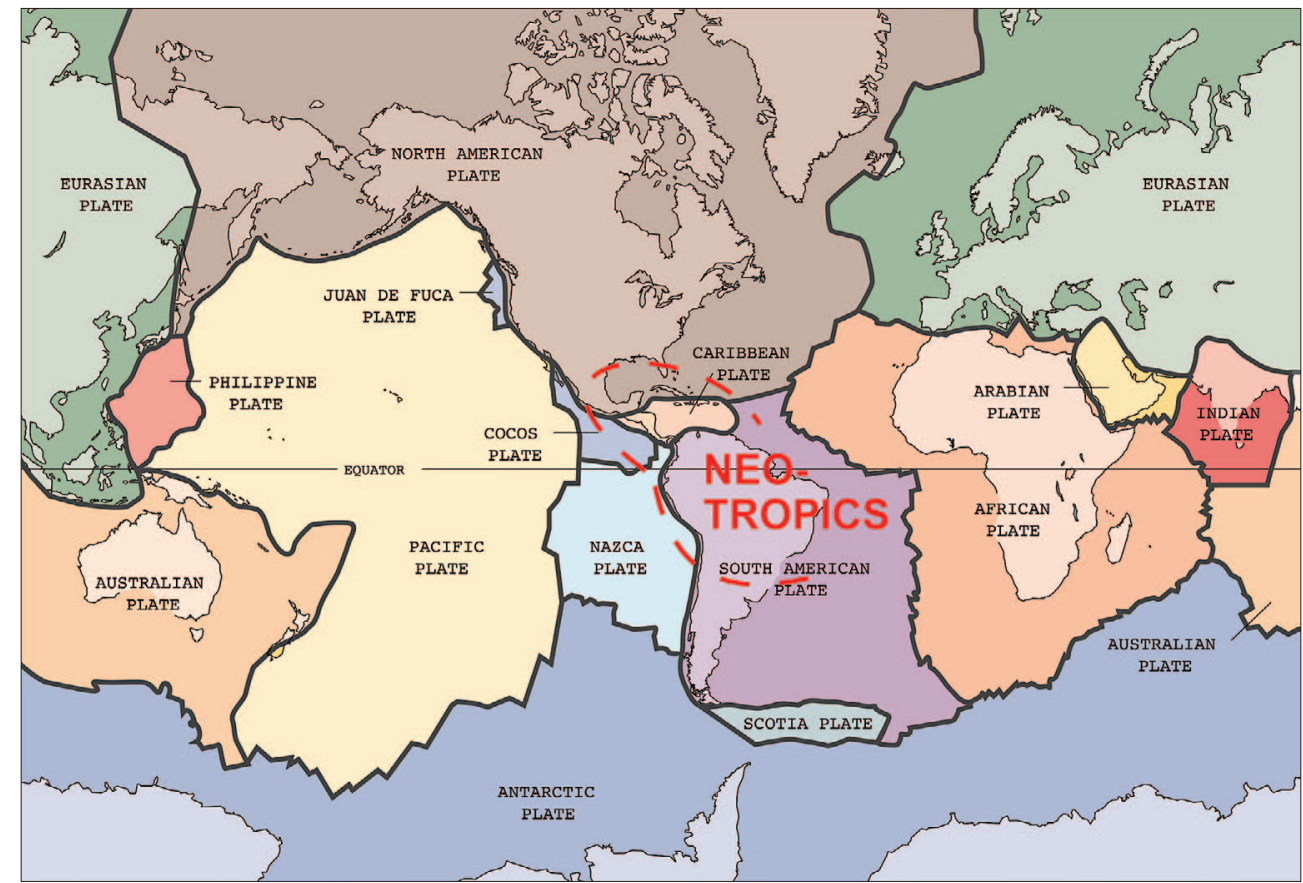

Gentry's (1982) survey, as many as $38 \%$ of all Neotropical plant species may belong to Andean-centred groups. Amazonian-centred groups, on the other hand, are characterised by having a high number of species in the Amazon Basin. Gentry exemplified this pattern using Berg's (1972) diversity map for the tribe Olmedieae (Moraceae; Fig. 4). Amazonian-centred groups, according to Gentry, may comprise some $33 \%$ of all Neotropical plant species.

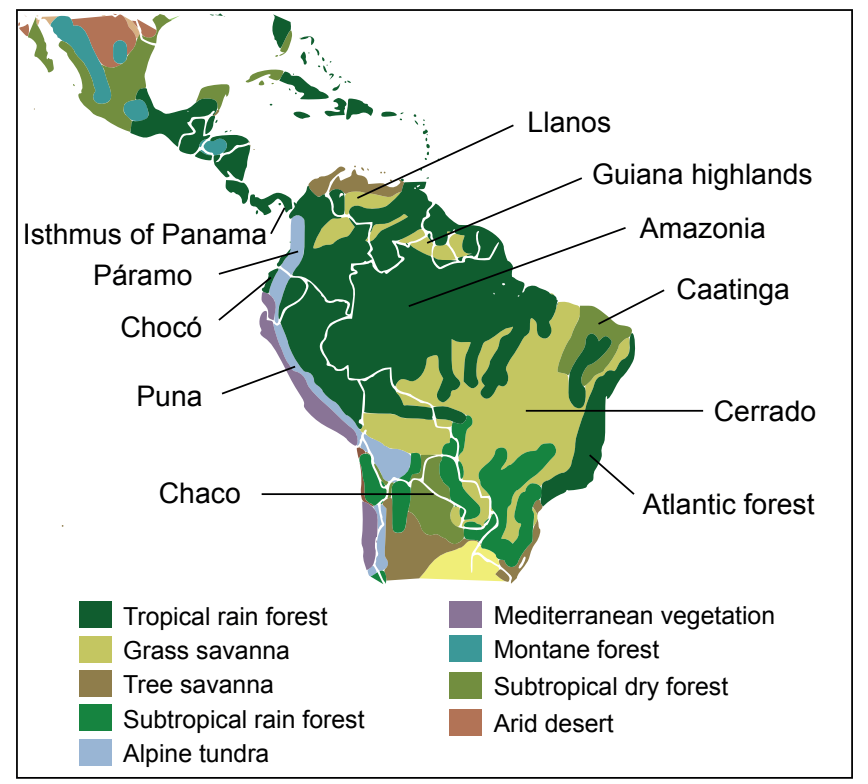

Fig. 2. Approximate natural distribution of major Neotropical biomes and vegetation types (adapted from Wikimedia Commons). Note that such maps differ widely in the literature in terms of resolution and delimitations. The Isthmus of Panama is also indicated.
Because the great majority of Neotropical plant species (71\% in Gentry's survey) belong to either one of these groups, Gentry concluded that "any explanation of the patterns of evolutionary diversification in these taxa will largely explain the richness of the Neotropical flora" (Gentry, 1982: 581). Although this was a bold and simplistic statement-hinting at an underlying belief that there should be a single explanation for Neotropical biodiversity - it set the stage for further exploration of factors responsible for the distribution patterns we observe today.

How did Neotropical biodiversity originate and evolve? - Many mechanisms have been proposed to have played a role in the historical assembly and evolution of Neotropical biodiversity. These may be very roughly classified into two major categories: "biotic" (e.g., soil adaptations; interactions with pollinators, dispersers and herbivores; niche conservatism; dispersal ability) and "abiotic" (e.g., time; rainfall, temperature and area; mountain uplift; hydrological changes). Below we present a short overview of some of the main diversification mechanisms proposed, discuss their validity, and provide general directions towards further testing. (see Antonelli \& al., 2010a for an overview of other "classical" hypotheses).

\section{BIOTIC MECHANISMS}

Soil adaptations. - Ecologists have long perceived and studied the correlation between edaphic variation and high species diversity, especially in tropical rain forests (e.g., Ashton, 1969; Gentry, 1981; Tuomisto \& al., 1995, 2003b; Clark \& al., 1999; Tuomisto \& al., 2003a). Fine \& al. (2005) showed that the majority of species in a phylogeny of tribe Protieae (Burseraceae) was strongly associated with only one of three main soil types in western Amazonia (clay, terrace soils and white 

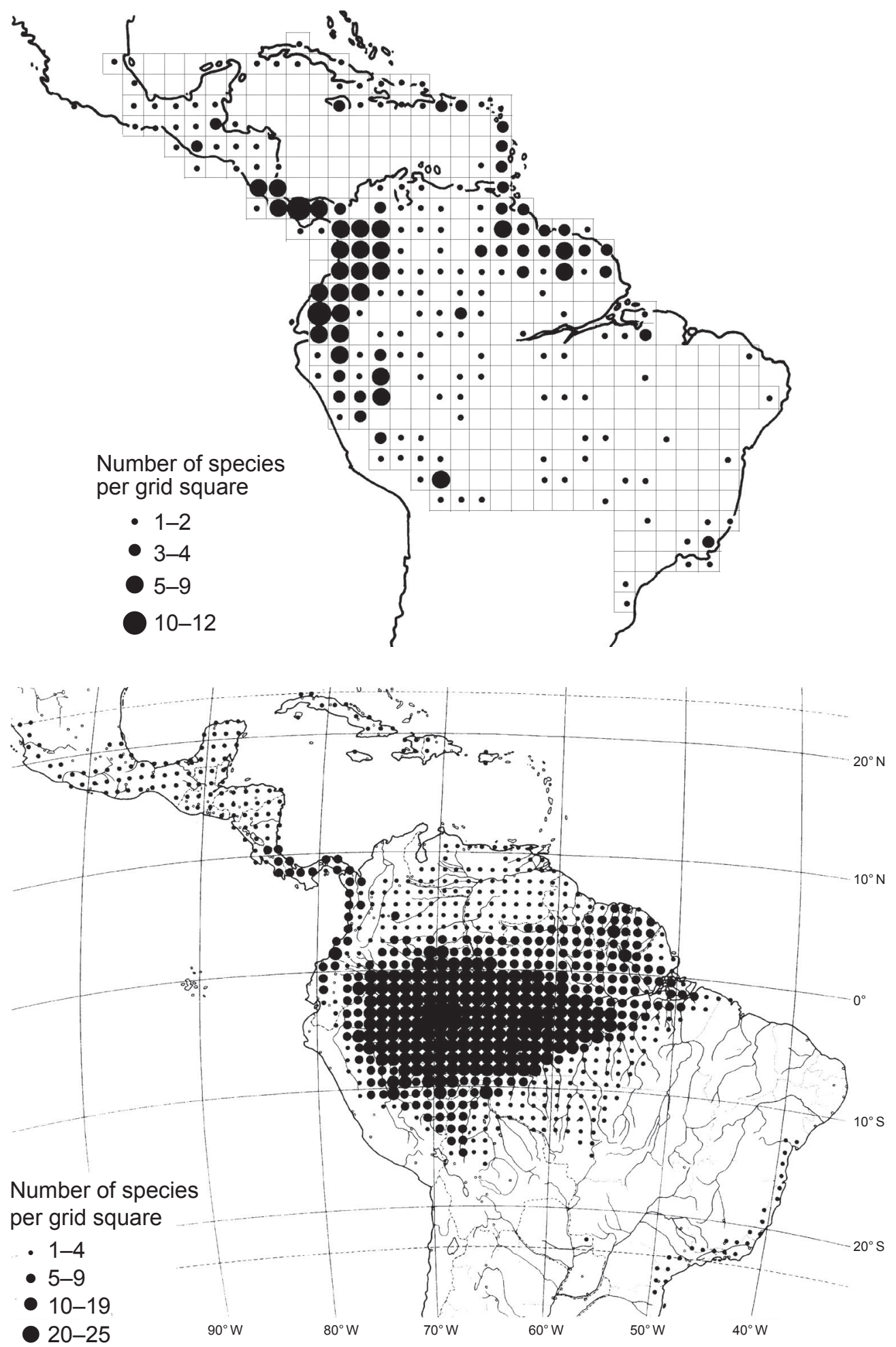

Fig. 3. Species diversity of a typical Andean-centred group: the genus Renealmia (Zingiberaceae). Redrawn from Maas (1977); the Trinidad grid square, mistakenly left blank by Maas was corrected in accordance with data in the text. Map by L. Andersson (unpublished).
Fig. 4. Species diversity of a typical Amazonian-centred group: tribe Olmedieae (Moraceae). Compiled from maps of individual species distributions in Berg (1972) and localities listed by Berg (1998). Map by L. Andersson. sand). Their study suggested that speciation by edaphic adaptation may have played an important role in the assembly of Amazonian biodiversity, but many similar studies are needed to ascertain the generality of the model.

Biotic interactions. - Interactions between plants and their pollinators, seed dispersal, and antagonists, and how such interactions have promoted or constrained species diversification, constitute a complex and still poorly studied research topic for the Neotropics.

The pollination of many Neotropical species has yet not been recorded, although in many families (such as orchids) there appears to be high pollinator specifity (Van der Cingel \& 
Van der Cingel, 2001). Although a general pollinator can often be deduced from a plant's 'pollination syndrome', actual observation may provide novel insights into plant-pollinator interactions. Some species in the Campanulaceae genus Burmeistera, for instance, have been shown to be pollinated daytime by hummingbirds and at night by bats (Muchhala, 2003). The evolutionary consequences of pollinator specificity vs. generality, and the exact mechanisms underlying floral specialisation, constitute a growing and promising field of Neotropical research (e.g., Kay \& al., 2005; Muchhala, 2007; Muchhala \& Potts, 2007; Tripp \& Manos, 2008; Armbruster \& Muchhala, 2009; Alcantara \& Lohmann, 2010, 2011; Muchhala \& al., 2010).

Plants and their herbivores constitute more than half of the organisms in tropical forests (Kursar \& al., 2009). Kursar \& al. (2009) found strong selection for divergent defensive traits in the legume genus Inga. Their results suggest that plant-herbivore interactions may function not only be as an important driver of speciation, but also as a means of maintaining high species diversity. However, plant antagonists (herbivores and pathogens) could in theory lead to the opposite effect, constraining diversification if the diversity of antagonists increases with host diversity (Ricklefs, 2010).

Dispersal ability. - The development and increased use of molecular dating techniques has indicated that long-distance dispersals have occurred much more often among plants than once thought (Renner, 2004, 2005; Queiroz, 2005).

Dispersals into South America have probably produced a net increase of species numbers on the continent, despite extinction caused by competition between the new arrivals and the autochthonous biota. The most important wave of migration is that following the uplift of the Panama Isthmus in the Late Pliocene ( 3.5 Ma), which connected South America to the north after some 100 million years of isolation. This event, known as the "Great American Biotic Interchange" (GABI), has been originally documented for mammals (Stehli \& Webb, 1985), but recently its role has been investigated in other taxa through meta-analyses of dated phylogenies (Weir $\&$ al., 2009; Cody \& al., 2010; Smith \& Klicka, 2010). The available evidence suggests that many plant lineages arrived in South America prior to the final closure of the Isthmus (Cody \& al., 2010), some considerably earlier (e.g., Antonelli \& al., 2009; Erkens \& al., 2009). These early dispersals might have been facilitated by "island hopping" across the proto-Greater Antilles in the Early Eocene ( $\sim 50 \mathrm{Ma})$ and the Greater Antilles and the Aves Ridge (GAARlandia) around the Eocene/Oligocene boundary (33-35 Ma; Iturralde-Vinent \& MacPhee, 1999), although the geological evidence for these island connections does not seem conclusive.

Repeated migrations from the north, which were almost always followed by in situ radiations (Hughes \& Eastwood, 2006; Pirie \& al., 2006; Erkens \& al., 2007, 2009; Moore \& Donoghue, 2007; Antonelli \& Sanmartín, in press), added to inferred transatlantic dispersals directly from Africa (Lavin \& al., 2004; Renner, 2004), suggests that dispersals from other landmasses have played an important role in the historical assembly of certain Neotropical biomes (Pennington \& Dick, 2004; Pennington \& al., 2006).
Niche conservatism. - The "tropical conservatism hypothesis" (Wiens \& Donoghue, 2004; Wiens, 2007) suggests that there are more plant species in the Neotropics simply because more plant lineages originated and diversified there owing to the long-term climatic stability of the region (i.e., longer times for speciation) and the tendency of species to retain their climatic niches over evolutionary time. The inferred high dispersal ability of many lineages mentioned above, combined with the inference that many plant taxa show a high degree of niche conservatism (Crisp \& al., 2009), support the idea that for plants it is often "easier to move than to evolve" (Donoghue, 2008: 11551). This might be an appropriate generalisation for some Neotropical biomes/ecosystems, such as seasonally dry tropical forests (see Pennington \& al., 2006 for a detailed distribution map). Phylogenetic analyses indicate that a significant proportion of the species in these biomes belong to lineages that dispersed from distant regions with similar environmental conditions (i.e., they were "pre-adapted"), rather than arriving from neighbouring biomes such as Amazonia (Hughes \& Eastwood, 2006; Pennington \& al., 2009, 2010).

However, biome conservatism may not be a general rule for the entire Neotropics. Simon \& al. (2009) showed that many lineages in the Cerrado have arrived from nearby ecosystems (rainforests, seasonally dry forests, subtropical grasslands and wetlands), independently adapting to fire conditions characteristic of this biome. Several other studies have similarly shown that considerable biotic interchange has occurred among Neotropical biomes and altitudinal zones within the same biome (e.g., Perret \& al., 2006; Antonelli \& al., 2009; Dušková \& al., 2010; Hoorn \& al., 2010).

Different biomes thus appear to have been assembled by different dominant processes, which could also be seen as they differ in their permeability to successful migrations (Pennington $\&$ al., 2010). Such differences may also become evident within biomes, as we gather more information from molecular phylogenies. In a recent review, for instance, Sklenár \& al. (in press) showed that about half of the plant genera in the Páramos have a temperate origin, showing niche conservatism (i.e., they were pre-adapted to the Páramo climate), while the other half of the surveyed genera are likely of tropical origin and have adapted in situ. Quantifying the extent of biotic interchange in the Neotropics would help understand the historical assembly of biomes and pinpoint biological corridors for future conservation.

\section{aBIOTIC MECHANISMS}

Time. - The oldest evolutionary explanation to explain the extraordinary diversity of the Neotropical region is probably the "time hypothesis", the idea that the species richness of a region is correlated to the amount of time available for speciation within the region (Wallace, 1878; Mittelbach \& al., 2007). According to this hypothesis, the geological isolation and long-term climatic stability of the South American continent would have favoured the gradual accumulation and/or preservation of lineages over time. After splitting from Africa 
in the mid-Cretaceous (ca. $100 \mathrm{Ma}$ ), South America remained isolated from other tropical continents, until a new connection was established with North America via the uplift of the Panama Isthmus ca. 3.5 Ma. Simpson (1980) coined the term "splendid isolation" to refer to the fact that the mammalian fauna of South America evolved and diversified during nearly 90 million years in what was effectively an "island continent". Also, compared to Australia and other Gondwanan landmasses, the Neotropical region has always been at about the same geographic latitude (close to the Equator), and therefore subjected to similar climatic conditions, so this long-term climatic stability would have favoured low extinction rates and the preservation of species over time (Stebbins, 1974; Mittelbach \& al., 2007).

This "museum model of diversification"- the notion of the Neotropics as a museum of lineages - is supported by some recent palaeontological and phylogenetic evidence, showing that the origin of several evolutionary radiations (crown diversification) in present-day Amazonia can be traced back to the early Neogene or even earlier (Hoorn \& al., 2010). However, other phylogenetic studies show evidence of a "cradle model" of diversification, with recent and rapid accumulation of species via high speciation rates, perhaps triggered by climatic shifts during the Pleistocene (Rull, 2011) or relatively recent tectonic events such as the Pliocene final uplift of the Andes (Gregory-Wodzicki, 2000; Hughes \& Eastwood, 2006) or the uplift of the Panama Isthmus. Increasing evidence suggests that these two models are not mutually exclusive, with many tropical groups exhibiting features of both museum and cradle diversification and varying speciation and extinction rates in their evolutionary histories (McKenna \& Farrell, 2006; Mittelbach \& al., 2007; Antonelli \& Sanmartín, in press).

Climate and area: Current patterns. - Ecologists have long recognised that high levels of rainfall, temperature and habitat heterogeneity are correlated with high species richness. Globally, a combined multipredictor model has been shown to explain $70 \%$ of the global variation in species richness (Kreft \& Jetz, 2007). Such models may in fact account for the much debated latitudinal gradient in species richness (Kreft \& Jetz, 2007), although dozens of alternative hypotheses have been proposed (Lomolino, 2005). It seems that climate plays an important role in determining species richness at large scales, whereas at smaller extents such correlation is often less evident or non-significant compared to a null expectation (Field \& al., 2009).

The effect of area (range sizes) on species richness has been studied more in animals (e.g., Rahbek \& Graves, 2001) than in plants (Field \& al., 2009), perhaps due to our scarcer knowledge on range sizes for Neotropical plant species. The effect of area on diversity may be difficult to model and separate from other variables such as habitat heterogeneity (Kreft \& al., 2006; Kisel $\&$ al., in press), but it appears to be a worse predictor of species richness than climate (Field \& al., 2009) or other correlates such as diversification rates (Svenning \& al., 2008).

Climate and area: Past responses to climate. - Although climate may thus be one of the most powerful global predictors of species richness today, its historical role in producing or maintaining Neotropical plant diversity is a matter of contention. Analyses of fossil pollen show correlation between high global temperatures in the Eocene and high plant diversity in the Neotropics (Jaramillo \& al., 2006), and indicate that global warming at the Paleocene/Eocene boundary (56.3 $\mathrm{Ma}$ ) has resulted in increases in species numbers for several plant families (Jaramillo \& al., 2010). However, a similar correlation is not evident for the Neogene, where the diversity of pollen morphospecies shows poor agreement with fluctuations in temperature (Hoorn \& al., 2010).

Perhaps the most important and debated link suggested between climate and species richness in the Neotropics concerns the "refuge theory" for Amazonia. During the past 2.6 $\mathrm{Ma}$, the Earth went through some 20 major glacial periods (Gates, 1993). Based on the observation that the main centres of avian endemism in northern South America are situated in zones that today receive the highest levels of precipitation, Haffer (1969) suggested that the rainforest cover in Amazonia changed repeatedly in response to global climatic oscillations. According to his hypothesis, lowland forest was fragmented into isolated refugia during cooler (drier) periods and expanded and condensed again during warmer (wetter) interglacials. As a result, allopatric speciation in forest refugia was promoted.

This Pleistocene refuge theory gained early support with the emergence of similar distribution patterns in many taxa, including plants (Prance, 1973, 1978, 1982; Andersson, 1979). However, criticism started soon to accumulate in many directions, including the lack of evidence for widespread aridification in Amazonia, the demonstration that perceived endemism centres were often artefacts of sampling, and the fact that the age of many Neotropical clades as inferred by molecular dating analyses predates the onset of Pleistocene glaciations (Nelson \& al., 1990; Bush, 1994; Knapp \& Mallet, 2003). Recently, Hoorn \& al. (2010) presented the most extensive review of the geological, fossil and molecular evidence for northern South America. Since most organism groups were already highly diverse prior to the onset of Pleistocene glaciations at 2.6 Ma, they concluded (Hoorn \& al., 2010, 2011) that Pleistocene dynamics - either as postulated by the refuge theory or by alternative processes (Rull, 2005, 2011)—cannot be claimed responsible for the outstanding levels of Neotropical species richness. The refuge theory has later been modified to apply to the entire Cenozoic, based on the assumption that climatic fluctuations can lead to allopatric speciation (Haffer, 2008 and references therein). However, the lack of biogeographic signal in certain Amazonian phylogenies (e.g., Kursar \& al., 2009) and recently developed null models of speciation (De Aguiar $\&$ al., 2009) challenge the view that allopatric speciation has been the dominant mode of speciation.

The effect of climatic fluctuations may have been more pronounced outside the Amazonian rainforest. Antonelli \& al. (2010b) suggested that climate cooling following the MidMiocene climatic optimum probably increased the geographical extent of rocky savannas in the Cerrado, promoting the expansion and diversification of a group of orchids. Global cooling might have had a comparable effect on all southern continents, promoting the expansion of open habitats and establishment of fire regimes, triggering the diversification of 
plants adapted to fire conditions (Simon \& al., 2009; Crisp \& al., 2010; Bytebier \& al., 2011).

Mountain uplift. - Extending over $5000 \mathrm{~km}$ along the western coast of South America, the Andean Cordillera constitutes the largest mountain chain directly adjacent to a tropical rain forest. Its initial uplift can be traced back to the Cretaceous (Milnes, 1987), and is thought to have roughly proceeded from south to north and from west to east. In the central and northern Andes, most of the uplift took place in the last $25 \mathrm{Ma}$, intensifying between 10 and $5 \mathrm{Ma}$, and with some segments of the Eastern Cordillera in the northern Andes having risen as recently as 5-2 Ma (Gregory-Wodzicki, 2000; Garzione \& al., 2008; Hoorn \& al., 2010).

Andean uplift may have increased diversification in several important ways (see Hoorn \& al., 2010 and references therein): (1) by increasing habitat heterogeneity in northern South America, and thus favouring adaptive radiations in newly formed montane habitats; (2) by creating a "biotic corridor" for taxa pre-adapted to montane conditions to increase their range; (3) by favouring allopatric speciation in montane taxa, separated by deep valleys and impassable ridges and peaks; (4) by producing geographic vicariance, and consequently genetic isolation, between lowland populations on both sides of the emerging mountains; (5) by acting as a "species pump", as newly formed lineages in the Andes may have dispersed into other Neotropical biomes and further radiated; (6) by increasing nutrient deposition in western Amazonia, following denudation of the rising mountains by rainfall (see below).

Hydrological changes: The Pebas system. - Among many things, the Andean uplift changed the entire hydrological configuration of northern South America. The current settings, with the Amazon river flowing eastwards and the Andean mountains fully formed, was only established some 7-2.5 Ma (see Hoorn \& al., 2010 and references therein; Wesselingh $\&$ al., 2010). There is now a general consensus that western Amazonia was dominated by aquatic settings, "the Pebas system", between ca. 24 and $10 \mathrm{Ma}$ (Hoorn \& al., 2010) (Fig. 5). Whether the Pebas system was a single lake that covered up to 1 million $\mathrm{km}^{2}$ (Wesselingh \& al., 2002) or a river system surrounded by lowland terra firme (= dry soil) forest areas, such as the Brazilian Pantanal (Latrubesse \& al., 2010), is however a matter of debate.

The nature of the Pebas system has important implications for our understanding of Neotropical plant evolution, since western Amazonia comprises sites with the highest alpha diversity measured in any tropical rainforest (Valencia \& al., 1994). The existence of a single mega-lake would imply that in situ diversification of trees adapted to dry land necessarily postdated its drainage (ca. 10-7 Ma), as pointed out by Antonelli $\&$ al. (2009). If diversification of clades endemic to western Amazonia are instead shown to extend further back than 11 $\mathrm{Ma}$, and biogeographical and fossil analyses confidently indicate that they evolved in situ (instead of evolving elsewhere, such as in non-flooded montane habitats, and subsequently migrating), this would provide independent evidence that the Pebas system was a river system interspersed with terra firme areas, rather than gigantic lake. Interestingly, the few molecular

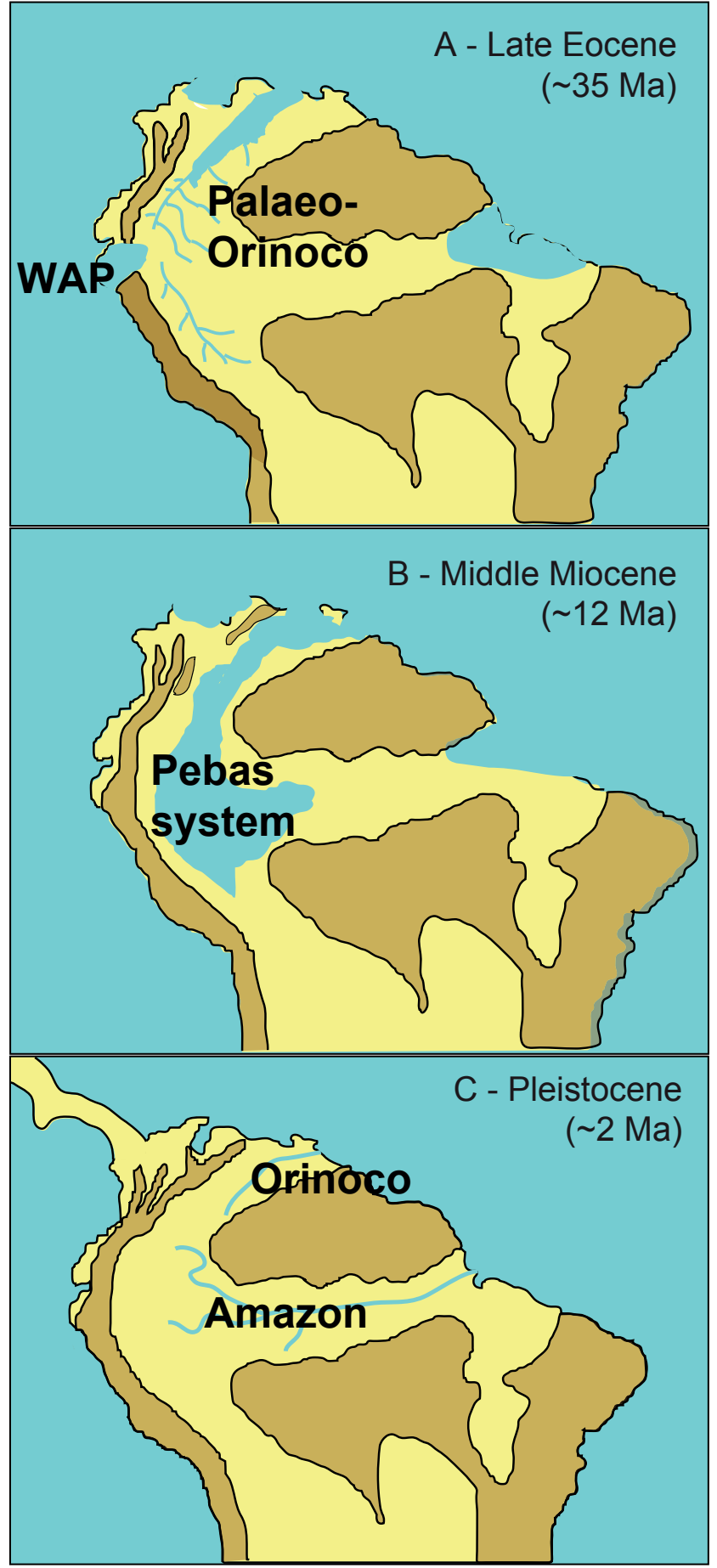

Fig. 5. Simplified landscape evolution of northern South America in the last $35 \mathrm{Ma}$ (adapted from Antonelli et al., 2009; Hoorn \& al., 2010). A, A northwards flowing fluvial system (the Subandean River System or palaeo-Orinoco) dominates the drainage of western Amazonia and the foreland Andean basins. A lowland corridor occasionally invaded by marine settings (the Western Andean Portal, WAP) may have limited biotic dispersal between the Northern and Central Andes. B, The Pebas system dominates western Amazonia. The WAP is uplifted, facilitating the dispersal of Andean taxa. C, South America is connected to Central America, the Pebas system is completely drained, and dispersal of terrestrial organisms is facilitated across most of the region. Light yellow, lowlands; brown, montane areas; blue, aquatic settings. 
dating studies that have dealt with a representative number of Amazonian trees seem to support the former scenario, i.e., recent and rapid radiation for the genera Inga (Richardson \& al., 2001; Lavin \& al., 2006) and Guatteria (Erkens \& al., 2007). However, biogeographical analyses necessary for testing this scenario may be complicated by recent range expansion into western Amazonia of species that once surrounded the Pebas system ("dispersal overwrite"; Pennington \& Dick, 2010).

Hydrological changes: The Western Andean Portal. Many plant families, such as Campanulaceae (Ayers, 1999), Calceolariaceae (Molau, 1988), Tropaeolaceae (Sparre \& Andersson, 1991), Loasaceae, Passifloraceae, Grossulariaceae (Weigend, 2002, 2004), Clusiaceae (M.H. Gustafsson, pers. comm.) and Alstroemeriaceae (Hofreiter \& Rodríguez, 2006), show a conspicuous disjunction between the Northern and Central Andes. These families contain genera or species groups mostly restricted to either north or south of a zone in southern Ecuador/northern Peru $\left(\sim 3^{\circ}-5^{\circ} \mathrm{S}\right.$; Fig. 5), referred to as the "Western Andean Portal" (WAP, Antonelli \& al., 2009), but also Huancabamba Depression, Huancabamba Deflexion, Marañón Portal, Guayaquil Gap, Northern Peruvian Low or Pirua Divide, all seemingly referring to roughly the same area (Antonelli \& al., 2009).

From the Eocene to the Middle Miocene ( 40-12 Ma), episodic marine incursions from the Pacific have been suggested to penetrate the WAP, which at the time was a lowland corridor separating the Northern from the Central Andes. Marine incursions probably ended in connection with the uplift of the Eastern Cordilleras of the Central and Northern Andes from the Middle Miocene onwards (13-11 Ma; Hoorn \& al., 1995, 2010; Hungerbühler \& al., 2002), allowing the Andes to be permanently connected by highlands. This may have created a new migration route between the Northern and Central Andes for organisms adapted to montane conditions (Antonelli \& al., 2009). Prior to the establishment of this "Andean highway", however, the WAP probably constituted a dispersal barrier for montane taxa, leading to species diversification on either side of the WAP but rather few dispersals across it. It should be noted, however, that by the time the WAP uplifted the northern Andes may have attained only about half of their present height (Gregory-Wodzicki, 2000), meaning that truly high altitude (Páramo) taxa were probably absent.

Hydrological changes: The palaeo-Orinoco and the Gentry pattern. - To date, no studies have attempted to explain the formation of the Gentry pattern (see above; Figs. 3 and 4). Gentry's own idea was that this pattern arose by differentiation from an originally more uniform pattern, and that the uniform pattern was a remnant of a more or less continuous West Gondwanan rain forest flora (Gentry 1982). Based on these premises, species richness of Andean-centred groups in northwestern South America was explained as a consequence of evolutionary radiation in certain lineages in response to environmental changes caused by the Andean orogeny. Gentry did not discuss at all how or when a diversity centre would have been formed in the central Amazonian basin.

Distributional disjunctions of organisms are commonly formed by the influence of a geographic barrier, but no such barrier exists today between the Andes and the Amazon Basin. It could therefore be assumed that eco-physiological constraints acted instead as barriers for lowland organisms, at the same time as taxa already adapted to montane habitats were unable to compete with lowland-adapted taxa at lower altitudes. However, as emphasized by Gentry (1982), while the representation of Andean-centred taxa is highest in the Andes, most species occur along the base and slopes of mountains, rather than at high altitudes. It is thus conceivable that if no geographic barrier existed between the Andes and Amazonia, biotic interchange between these two areas would have taken place continuously, which in turn should have promoted speciation through gradual adaptation to slightly different altitudes (Smith \& al., 1997). However, if this was the case for most taxa, no clear biogeographical pattern should be observed today separating Andean-centred and Amazonian-centred groups.

From the Cretaceous until the end of the Oligocene (ca. 112-24 Ma), a fluvial system referred to as the palaeo-Orinoco dominated the drainage of northwestern Amazonia and the foreland Andean basins towards Lake Maracaibo, on the Caribbean coast (Fig. 5). Then, in the Early Miocene (ca. $23 \mathrm{Ma}$ ), geotectonic changes in the Amazon Basin associated with the ongoing uplift of the Eastern Cordillera in the Central Andes caused western Amazonia to gradually become submerged, creating the Pebas system (see above). Further uplift, affecting mainly the Eastern Andean Cordilleras, presumably caused the areas west of the Guiana Shield to emerge, closing the Caribbean connection of the palaeo-Orinoco and shifting the drainage of the Amazon Basin eastwards, causing the demise of the Pebas system (Hoorn \& al., 2010; Wesselingh \& al., 2010) (Fig. 5C).

A remarkable fit can be observed between the hydrological scenario outlined here (Fig. 5) and the distributional patterns depicted in Figs. 3 and 4. It seems therefore possible to speculate that the "missing" long-lasting barrier needed for creating the disjuction between Andean-centred and Amazonian-centred groups could have been the palaeo-Orinoco and its successor, the Pebas system.

The WAP and the palaeo-Orinoco are of special relevance for understanding the biogeography and distribution of Neotropical plants, because they could potentially be used to test the role of ecological constraints vs. historical barriers in shaping current patterns of plant distributions. If they indeed constituted dispersal barriers, biogeographical analyses based on dated phylogenies of groups distributed across these presumed barriers (e.g., Antonelli \& al., 2009; Santos \& al., 2009) should infer very few dispersals before the disappearance of the barriers, followed by a significant increase in dispersals. If no significant shifts in dispersal rates can be detected, this would favour the idea that eco-physiological constraints (niche conservatism) played a more important role in determining the disjunct patterns observed today. Phyloclimatic modelling of niche preferences (Yesson \& Culham, 2006), especially in combination with realistic palaeoclimatic reconstructions (e.g., Sepulchre \& al., 2006) and biogeographic inference taking into account phylogenetic uncertainty and dynamic biogeographical settings (Smith, 2009) could provide further insights on the issue. 


\section{USING DATED PHYLOGENIES TO HELP UNDERSTAND NEOTROPICAL DIVERSIFICATION}

A major problem in evolutionary studies is how to determine the actual cause(s) of speciation. We have outlined here some-but certainly not all — of the major mechanisms and hypotheses proposed for explaining Neotropical diversification, but there is no consensus regarding how (or even whether) they can be tested. Dated molecular phylogenies (molecular chronograms), especially in conjunction with information from the fossil record, can help test some of the hypotheses that contain a strong temporal prediction, such as (1) that a large proportion of South American species have been "inherited" from Gondwana, i.e., they existed already before the separation of South America and Africa ca. $100 \mathrm{Ma}$; or (2) that the high levels of Neotropical diversity originated as a consequence of Pleistocene dynamics, i.e., in the last 2.6 Ma.

To illustrate how this may be done, we present here (Fig. 6) a number of lineage-through-time (LTT) plots of dated Neotropical phylogenies of plants and animals (Antonelli \& al., in prep.). The principle of LTT plots is simple: the number of lineages in a molecular chronogram, or the logarithm of that number, is plotted as a function of time. Although this graphical method has limited statistical value in testing hypotheses (Nee \& al., 1992; Paradis \& al., 2004), it has been widely used in the literature for visualising the temporal pattern of lineage accumulation over time from reconstructed (i.e., including extant taxa only) phylogenies. A visual inspection of Fig. 6 makes evident that both the "Gonwana" and "Pleistocene" hypotheses may be discarded as the major causes of Neotropical biodiversity: (1) prior to the separation of Africa and South America, no modern Neotropical clades (of the ones analysed here) existed (i.e., no most recent common ancestors can be traced back to Gondwanan times); and (2) by the time Pleistocene climatic changes began, most modern groups had already begun to diversify (Hoorn \& al., 2011).

Dated phylogenies can thus be used to test simple temporal hypotheses of diversification, as well as to provide insights into the historical assembly of species-rich biomes (Pennington \& al., 2006, 2010; Simon \& al., 2009). Nevertheless, there are many limitations and caveats associated with molecular-dating analyses, and results are highly influenced by taxon sampling, methodology, and fossil calibrations (e.g., Linder \& al., 2005; Renner, 2005; Ricklefs, 2007). As pointed out by Pennington \& Dick (2010) a further and perhaps even harder problem to tackle is that several of the proposed hypotheses of diversification overlap in time, such as the Andean uplift, climatic fluctuations, and postulated island chains between South and North America (Fig. 6).

Phylogenetic correlation analyses (e.g., Pagel \& Meade, 2006; Freckleton \& al., 2008) could be increasingly used to test whether increases in diversification rates can be associated with specific events, such as dispersal into a new region or acquisition of a morphological "key innovation" (e.g., Ree, 2005; Moore \& Donoghue, 2007, 2009; Antonelli \& al., 2011; Antonelli \& Sanmartín, in press; Humphreys \& al., in press). However, they too are sensitive to a series of potential pitfalls
Fig. 6. Lineage-through-time (LTT) plots for a representative sample of dated phylogenies of Neotropical organisms (from Antonelli \& al., in prep.), depicting 14 plant and 30 animal phylogenies. The shaded boxes represent the approximate duration of some geological and geographic events suggested to have fostered the dispersal and radiation of Neotropical organisms. Global temperature curve from Zachos \& al. (2001). GAARlandia: Greater Antilles and Aves Ridge.

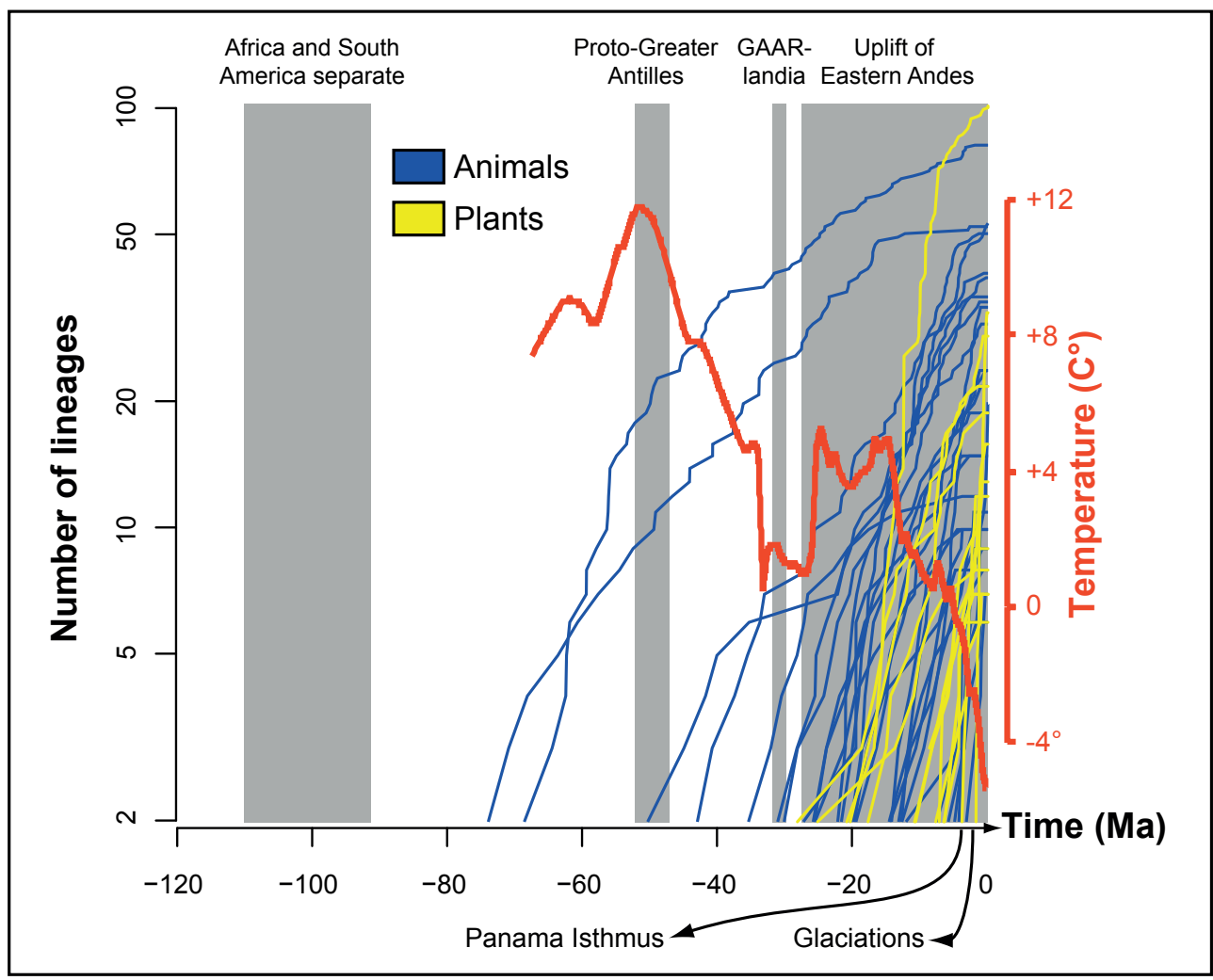


including poor taxon sampling, and it is exceptionally difficult to separate speciation and extinction rates from net diversification estimates (Crisp \& Cook, 2009; Cusimano \& Renner, 2010; Rabosky, 2010). Finally, such analyses can still only provide correlational links, whereas substantial theoretical and experimental work may be necessary to distinguish between correlation, causation, and effect, with an acceptable level of confidence (e.g., Armbruster \& Muchhala, 2009).

\section{GAINED INSIGHTS, CURRENT CHALLENGES AND FUTURE PERSPECTIVES}

Gentry (1982) suggested that the Andean uplift has played a central role in generating the "excess" of species found in the Neotropics as compared to other tropical regions. Thirty years later, technological and other intellectual advances have provided us with new tools to pursue the question outlined in the title of this paper. The evidence gathered so far from molecular phylogenies and the fossil record has confirmed the key role of geotectonic processes in re-shaping northern South America and setting the stage for species diversifications (Hoorn \& al., 2010), but it has also pointed out that Neotropical biodiversity is the product of many distinct, and often interacting, evolutionary processes - several of which we are just beginning to realise and understand. It is also important to emphasise that the processes and events that have led to increases in biodiversity may not necessarily be the same as those that maintain it over longer time scales.

Big problems demand big science. We need to advance the way we accumulate and use evidence from as many organismic groups as possible, creating phylogenies that are densely sampled both taxonomically and genetically (e.g., by using new ultra-high-throughput DNA sequencing technologies and plant material from ecological inventory plots). Increased taxon sampling in phylogenies, besides improving our estimates on the biogeography and diversification of a clade, may lead to an appreciation of the true diversity of the Neotropics including "cryptic" species (Condon \& al., 2008; Smith \& al., 2008). At the same time, we need to put our results into a broader perspective, developing methods that can test the generality of postulated hypotheses across individual studies (e.g., Field \& al., 2009). Substantial insights are to be gained through inter-disciplinary scientific collaborations (integrating, for instance, botany and zoology; biology, geology, palaeontology and climatology; ecology, classical taxonomy and molecular systematics).

The origins and evolution of Neotropical diversity have intrigued scientists for centuries, and will most probably continue to do so for centuries to come. However, we now face an unprecedently difficult task, as much of this diversity is at considerable risk of disappearing due to habitat destruction and climate change (Hubbell \& al., 2008; Svenning \& Condit, 2008). As biologists we must actively contribute to disseminate our knowledge on biodiversity, how it has evolved, and how the gathered evidence can help us in choosing the most effective conservation measures (Hendry \& al., 2010).

\section{ACKNOWLEDGEMENTS}

A.A. was supported by grants from the Swedish Research Council, the Royal Swedish Academy of Sciences, Royal Society of Arts and Sciences in Göteborg, Kungliga och Hvitfeldtska Stiftelsen, Adlerbertska Stipendiestiftelsen, Stiftelsen Paul och Marie Berghaus donationsfond, Carl Tryggers Stiftelse and Helge Ax:son Johnsons Stiftelse. I.S. was supported by a starting grant from the Spanish Higher Council of Scientific Research (CSIC 200830I228) and by the Ministry of Science and Technology (CGL2009-13322-C03-01). We are grateful to the comments by $\mathrm{C}$. Hughes and an anonymous reviewer, which have considerably contributed to improving this manuscript. We also thank Karol Marhold for organising this issue and Toby Pennington, Carina Hoorn, Frank Wesselingh, Hans ter Steege, Henry Hooghiemstra, Claes Persson, Aelys Humphreys, and several other colleagues for fruitful discussions and support. This review is partly based on the doctoral thesis of A.A. (University of Gothenburg, 2008). Our apologies to all colleagues whose work we did not mention because of our ignorance or because of space constraints. We wish to dedicate this paper to late Professor Lennart Andersson, who first inspired us to study the Neotropical flora and introduced us to the "Gentry pattern".

\section{LITERATURE CITED}

Alcantara, S. \& Lohmann, L.G. 2010. Evolution of floral morphology and pollination system in Bignonieae (Bignoniaceae). Amer. J. Bot. 97: 782-796.

Alcantara, S. \& Lohmann, L.G. 2011. Contrasting phylogenetic signals and evolutionary rates in floral traits of Neotropical lianas. Biol. J. Linn. Soc. 102: 378-390.

Andersson, L. 1979. Multi-layered distribution patterns and the hypothesis of rain forest refugia. Bot. Not. 132: 185-190.

Antonelli, A., Humphreys, A.M., Lee, W.G. \& Linder, H.P. 2011. Absence of mammals and the evolution of New Zealand grasses. Proc. Roy. Soc. London, Ser. B, Biol. Sci. 278: 695-701.

Antonelli, A., Nylander, J.A.A., Persson, C. \& Sanmartín, I. 2009. Tracing the impact of the Andean uplift on Neotropical plant evolution. Proc. Natl. Acad. Sci. U.S.A. 106: 9749-9754.

Antonelli, A., Quijada-Mascareñas, A., Crawford, A.J., Bates, J.M., Velazco, P.M. \& Wüster, W. 2010a. Molecular studies and phylogeography of Amazonian tetrapods and their relation to geological and climatic models. Pp. 386-404 in: Hoorn, C. \& Wesselingh, F. (eds.), Amazonia: Landscape and species evolution, 1st ed. Oxford: Wiley-Blackwell.

Antonelli, A. \& Sanmartín, I. In press. Mass extinction, gradual cooling, or rapid radiation? Reconstructing the spatiotemporal evolution of the ancient angiosperm genus Hedyosmum (Chloranthaceae) using empirical and simulated approaches. Syst. Biol.

Antonelli, A., Verola, C.F., Parisod, C. \& Gustafsson, A.L.S. 2010b. Climate cooling promoted the expansion and radiation of a threatened group of South American orchids (Epidendroideae: Laeliinae). Biol. J. Linn. Soc. 100: 597-607.

Armbruster, W.S. \& Muchhala, N. 2009. Associations between floral specialization and species diversity: Cause, effect, or correlation? Evol. Ecol. 23: 159-179.

Ashton, P. 1969. Speciation among tropical forest trees: Some deductions in the light of recent evidence. Biol. J. Linn. Soc. 1: 155-196.

Ayers, T. 1999. Biogeography of Lysipomia (Campanulaceae), a high elevation endemic: An illustration of species richness at the Huancabamba Depression, Peru. Arnaldoa 6: 13-28.

Berg, C. 1972. Olmedieae Brosimeae (Moraceae). Flora Neotropica Monograph 7. New York: Hafner. 
Berg, C. 1998. Moraceae (excl. Ficus). Vol. 60 of: Harling, G. \& Andersson, L. (eds.), Flora of Ecuador. Department of Systematic Botany, University of Göteborg and the Section for Botany, Riksmuseum, Stockholm.

Buckley, L.B., Davies, T.J., Ackerly, D.D., Kraft, N.J.B., Harrison, S.P., Anacker, B.L., Cornell, H.V., Damschen, E.I., Grytnes, J.A., Hawkins, B.A., McCain, C.M., Stephens, P.R. \& Wiens, J.J. 2010. Phylogeny, niche conservatism and the latitudinal diversity gradient in mammals. Proc. Roy. Soc. London, Ser. B, Biol. Sci. 277: 2131-2138.

Bush, M.B. 1994. Amazonian speciation: A necessarily complex model. J. Biogeogr. 21: 5-17.

Bytebier, B., Antonelli, A., Bellstedt, D.U. \& Linder, H.P. 2011. Estimating the age of fire in the Cape flora of South Africa from an orchid phylogeny. Proc. Roy. Soc. London, Ser. B, Biol. Sci. 278: 188-195.

Clark, D.B., Palmer, M.W. \& Clark, D.A. 1999. Edaphic factors and the landscape-scale distributions of tropical rain forest trees. Ecology 80: 2662-2675.

Cody, S., Richardson, J.E., Rull, V., Ellis, C. \& Pennington, R.T. 2010. The Great American Biotic Interchange revisited. Ecography 33: 326-332

Condon, M.A., Scheffer, S.J., Lewis, M.L. \& Swensen, S.M. 2008 Hidden neotropical diversity: Greater than the sum of its parts. Science 320: 928-931.

Crisp, M.D., Arroyo, M.T.K., Cook, L.G., Gandolfo, M.A., Jordan, G.J., McGlone, M.S., Weston, P.H., Westoby, M., Wilf, P. \& Linder, H.P. 2009. Phylogenetic biome conservatism on a global scale. Nature 458: 754-756.

Crisp, M.D. \& Cook, L.G. 2009. Explosive radiation or cryptic mass extinction? Interpreting signatures in molecular phylogenies. Evolution 63: 2257-2265.

Crisp, M.D., Isagi, Y., Kato, Y., Cook, L.G. \& Bowman, D. 2010. Livistona palms in Australia: Ancient relics or opportunistic immigrants? Molec. Phylog. Evol. 54: 512-523.

Cusimano, N. \& Renner, S.S. 2010. Slowdowns in diversification rates from real phylogenies may not be real. Syst. Biol. 59: 458-464.

Darwin, C. 1909. The voyage of the Beagle. From The Harvard Classics, vol. 29. New York: P.F. Collier \& Son.

De Aguiar, M.A.M., Baranger, M., Baptestini, E.M., Kaufman, L. \& Bar-Yam, Y. 2009. Global patterns of speciation and diversity. Nature 460: 384-387.

Donoghue, M.J. 2008. A phylogenetic perspective on the distribution of plant diversity. Proc. Natl. Acad. Sci. U.S.A. 105: 11549-11555.

Dušková, E., Kolář, F., Sklenár, P., Rauchová, J., Kubešová, M., Fér, T., Suda, J. \& Marhold, K. 2010. Genome size correlates with growth form, habitat and phylogeny in the Andean genus Lasiocephalus (Asteraceae). Preslia 82: 127-148.

Erkens, R.H.J., Chatrou, L.W., Maas, J.W., Van der Niet, T. \& Savolainen, V. 2007. A rapid diversification of rainforest trees (Guatteria; Annonaceae) following dispersal from Central into South America. Molec. Phylog. Evol. 44: 399-411.

Erkens, R.H.J., Maas, J.W. \& Couvreur, T.L.P. 2009. From Africa via Europe to South America: Migrational route of a species-rich genus of Neotropical lowland rain forest trees (Guatteria, Annonaceae). J. Biogeogr. 36: 2338-2352.

Field, R., Hawkins, B.A., Cornell, H.V., Currie, D.J., Diniz-Filho, J.A.F., Guégan, J.F., Kaufman, D.M., Kerr, J.T., Mittelbach, G.G., Oberdorff, T., O'Brien, E.M. \& Turner, J.R.G. 2009. Spatial species-richness gradients across scales: A meta-analysis. J. Biogeogr. 36: 132-147.

Fine, P.V.A., Daly, D.C., Villa-Munoz, G., Mesones, I. \& Cameron, K.-M. 2005. The contribution of edaphic heterogeneity to the evolution and diversity of Burseraceae trees in the western Amazon. Evolution 59: 1464-1478.

Freckleton, R.P., Phillimore, A.B. \& Pagel, M. 2008. Relating traits to diversification: A simple test. Amer. Naturalist 172: 102-115.
Garzione, C.N., Hoke, G.D., Libarkin, J.C., Withers, S., MacFadden, B., Eiler, J., Ghosh, P. \& Mulch, A. 2008. Rise of the Andes. Science 320: 1304-1307.

Gates, D.M. 1993. Climate change and its biological consequences. Sunderland, Massachusetts: Sinauer.

Gentry, A.H. 1981. Distributional patterns and an additional species of the Passiflora vitifolia complex: Amazonian species diversity due to edaphically differentiated communities. Pl. Syst. Evol. 137: 95-105.

Gentry, A.H. 1982. Neotropical floristic diversity: Phytogeographical connections between Central and South America, Pleistocene climatic fluctuations, or an accident of the Andean orogeny? Ann. Missouri Bot. Gard. 69: 557-593.

Govaerts, R. 2001. How many species of seed plants are there? Taxon 50: 1085-1090

Gregory-Wodzicki, K.M. 2000. Uplift history of the Central and Northern Andes: A review. Bull. Geol. Soc. Amer. 112: 1091-1105.

Haffer, J. 1969. Speciation in amazonian forest birds. Science 165: $131-137$.

Haffer, J. 20 08 . Hypotheses to explain the origin of species in Amazonia. Brazil. J. Biol. 68: 917-947.

Hendry, A.P., Lohmann, L.G., Conti, E., Cracraft, J., Crandall, K.A., Faith, D.P., Häuser, C., Joly, C.A., Kogure, K., Larigauderie, A., Magallón, S., Moritz, C., Tillier, S., Zardoya, R., Prieur-Richard, A., Walther, B.A., Yahara, T. \& Donoghue, M.J. 2010. Evolutionary biology in biodiversity science, conservation, and policy: A call to action. Evolution 64: 1517-1528

Hillebrand, H. 2004. On the generality of the latitudinal diversity gradient. Amer. Naturalist 163: 192-211.

Hofreiter, A. \& Rodríguez, E. 2006. The Alstroemeriaceae in Peru and neighbouring areas. Revista Peruana Biol. 13: 5-69.

Hoorn, C., Guerrero, J., Sarmiento, G.A. \& Lorente, M.A. 1995. Andean tectonics as a cause for changing drainage patterns in Miocene northern South America. Geology 23: 237-240.

Hoorn, C., Wesselingh, F.P., Ter Steege, H., Bermudez, M.A., Mora, A., Sevink, J., Sanmartin, I., Sanchez-Meseguer, A., Anderson, C.L., Figueiredo, J.P., Jaramillo, C., Riff, D., Negri, F.R., Hooghiemstra, H., Lundberg, J., Stadler, T., Sarkinen, T. \& Antonelli, A. 2010. Amazonia through time: Andean uplift, climate change, landscape evolution, and biodiversity. Science 330: 927-931.

Hoorn, C., Wesselingh, F.P., Ter Steege, H., Bermudez, M.A., Mora, A., Sevink, J., Sanmartín, I., Sanchez-Meseguer, A., Anderson, C.L., Figueiredo, J.P., Jaramillo, C., Riff, D., Negri, F.R., Hooghiemstra, H., Lundberg, J., Stadler, T., Särkinen, T. \& Antonelli, A. 2011. Origins of biodiversity - Response. Science 331: 399-400.

Hubbell, S.P., He, F., Condit, R., Borda-de-Água, L., Kellner, J. \& Ter Steege, H. 2008. How many tree species are there in the Amazon and how many of them will go extinct? Proc. Natl. Acad. Sci. U.S.A. 105: 11498-11504.

Hughes, C. \& Eastwood, R. 2006. Island radiation on a continental scale: Exceptional rates of plant diversification after uplift of the Andes. Proc. Natl. Acad. Sci. U.S.A. 103: 10334-10339.

Humboldt, A. 1820. Voyage aux regions equinoxiales $d u$ Nouveau Continent. Paris: N. Mazé.

Humphreys, A.M., Antonelli, A., Pirie, M.D. \& Linder, H.P. In press. Ecology and evolution of the diaspore "burial syndrome". Evolution. DOI: 10.1111/j.1558-5646.2010.01184.x.

Hungerbühler, D., Steinmann, M., Winkler, W., Seward, D., Egüez, A., Peterson, D.E., Helg, U. \& Hammer, C. 2002. Neogene stratigraphy and Andean geodynamics of southern Ecuador. Earth Sci. Rev. 57: 75-124.

Iturralde-Vinent, M.A. \& MacPhee, R.D.E. 1999. Paleogeography of the Caribbean region: Implications for Cenozoic biogeography. Bull. Amer. Mus. Nat. Hist. 238: 1-95.

Jaramillo, C., Ochoa, D., Contreras, L., Pagani, M., Carvajal-Ortiz, H., Pratt, L.M., Krishnan, S., Cardona, A., Romero, M., Quiroz, L., Rodriguez, G., Rueda, M.J., de la Parra, F., Morón, S., 
Green, W., Bayona, G., Montes, C., Quintero, O., Ramirez, R., Mora, G., Schouten, S., Bermudez, H., Navarrete, R., Parra, F., Alvarán, M., Osorno, J., Crowley, J.L., Valencia, V. \& Vervoort, J. 2010. Effects of rapid global warming at the Paleocene-Eocene boundary on Neotropical vegetation. Science 330: 957-961.

Jaramillo, C., Rueda, M.J. \& Mora, G. 2006 . Cenozoic plant diversity in the neotropics. Science 311: 1893-1896.

Kay, K.M., Reeves, P.A., Olmstead, R.G. \& Schemske, D.W. 2005. Rapid speciation and the evolution of hummingbird pollination in neotropical Costus subgenus Costus (Costaceae): Evidence from nrDNA its and ETS sequences. Amer. J. Bot. 92: 1899-1910.

Kisel, Y., McInnes, L., Toomey, N.H.\& Orme, C.D.L. In press. How diversification rates and diversity limits combine to create largescale species-area relationships. Philos. Trans., Ser. B

Knapp, S. \& Mallet, J. 2003. Refuting refugia? Science 300: 71-72.

Kozak, K.H. \& Wiens, J.J. 2007. Climatic zonation drives latitudinal variation in speciation mechanisms. Proc. Roy. Soc. London, Ser. B, Biol. Sci. 274: 2995-3003.

Kreft, H. \& Jetz, W. 2007. Global patterns and determinants of vascular plant diversity. Proc. Natl. Acad. Sci. U.S.A. 104: 5925-5930.

Kreft, H., Sommer, J.H. \& Barthlott, W. 2006. The significance of geographic range size for spatial diversity patterns in Neotropical palms. Ecography 29: 21-30.

Kricher, J. 1999. A neotropical companion: An introduction to the animals, plants, and ecosystems of the New World tropics, 2 nd ed. Princeton: Princeton University Press.

Kursar, T.A., Dexter, K.G., Lokvam, J., Pennington, R.T., Richardson, J.E., Weber, M.G., Murakami, E.T., Drake, C., McGregor, R. \& Coley, P.D. 2009. The evolution of antiherbivore defenses and their contribution to species coexistence in the tropical tree genus Inga. Proc. Natl. Acad. Sci. U.S.A. 106: 18073-18078.

Latrubesse, E.M., Cozzuol, M., Da Silva-Caminha, S.A.F., Rigsby, C.A., Absy, M.L. \& Jaramillo, C. 2010. The Late Miocene paleogeography of the Amazon Basin and the evolution of the Amazon River system. Earth Sci. Rev. 99: 99-124.

Lavin, M., Pennington, R., Lewis, G. \& Ratter, J. 2006. Floristic and geographic stability of discontinuous seasonally dry tropical forests explains patterns of plant phylogeny and endemism. Pp. 433-447 in: Pennington, R.T., Lewis, G. \& Ratter, J.A. (eds.), Neotropical savannas and seasonally dry forests: Plant biodiversity, biogeographic patterns and conservation. Boca Raton: CRC Press.

Lavin, M., Schrire, B.P., Lewis, G., Pennington, R.T., DelgadoSalinas, A., Thulin, M., Hughes, C.E., Matos, A.B. \& Wojciechowski, M.F. 2004. Metacommunity process rather than continental tectonic history better explains geographically structured phylogenies in legumes. Philos. Trans., Ser. B 359: 1509-1522.

Linder, H.P., Hardy, C.R. \& Rutschmann, F. 2005. Taxon sampling effects in molecular clock dating: An example from the African Restionaceae. Molec. Phylog. Evol. 35: 569-582.

Lomolino, M.V. 2005. Biogeography, 3rd ed. Sunderland, Massachusetts: Sinauer.

Maas, P. 1977. Renealmia (Zingiberaceae-Zingiberoideae) and Costoideae additions (Zingiberaceae). Flora Neotropica Monograph 18. Bronx, New York: New York Botanical Garden.

McKenna, D.D. \& Farrell, B.D. 2006. Tropical forests are both evolutionary cradles and museums of leaf beetle diversity. Proc. Natl. Acad. Sci. U.S.A. 103: 10947-10951.

Milnes, A.G. 1987. Tectonic evolution of the southern Andes, Tierra del Fuego: A summary. Pp. 173-177 in: Schaer, J.-P. \& Rodgers, J. (eds.), The anatomy of mountain ranges. Princenton: Princeton University Press.

Mittelbach, G.G., Schemske, D.W., Cornell, H.V., Allen, A.P., Brown, J.M., Bush, M.B., Harrison, S.P., Hurlbert, A.H., Knowlton, N., Lessios, H.A., McCain, C.M., McCune, A.R., McDade, L.A., McPeek, M.A., Near, T.J., Price, T.D., Ricklefs, R.E., Roy, K., Sax, D.F., Schluter, D., Sobel, J.M. \& Turelli, M. 2007. Evolution and the latitudinal diversity gradient: Speciation, extinction and biogeography. Ecol. Lett. 10: 315-331.

Molau, U. 1988. Scrophulariaceae, part 1, Calceolarieae. Flora Neotropica Monograph 47. Bronx, New York: New York Botanical Garden.

Moore, B.R. \& Donoghue, M.J. 2007. Correlates of diversification in the plant clade dipsacales: Geographic movement and evolutionary innovations. Amer. Naturalist 170: S28-S55.

Moore, B.R. \& Donoghue, M.J. 2009. A Bayesian approach for evaluating the impact of historical events on rates of diversification. Proc. Natl. Acad. Sci. U.S.A. 106: 4307-4312.

Muchhala, N. 2003. Exploring the boundary between pollination syndromes: Bats and hummingbirds as pollinators of Burmeistera cyclostigmata and B. tenuiflora (Campanulaceae). Oecologia 134: 373-380.

Muchhala, N. 2007. Adaptive trade-off in floral morphology mediates specialization for flowers pollinated by bats and hummingbirds. Amer. Naturalist 169: 494-504.

Muchhala, N., Brown, Z., Armbruster, W.S. \& Potts, M.D. 2010. Competition drives specialization in pollination systems through costs to male fitness. Amer. Naturalist 176: 732-743.

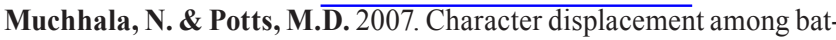
pollinated flowers of the genus Burmeistera: Analysis of mechanism, process and pattern. Proc. Roy. Soc. London, Ser. B, Biol. Sci. 274: 2731-2737.

Nee, S., Mooers, A.O. \& Harvey, P.H. 1992. Tempo and mode of evolution revealed from molecular phylogenies. Proc. Natl. Acad. Sci. U.S.A. 89: 8322-8326.

Nelson, B.W., Ferreira, C.A.C., Da Silva, M.F. \& Kawasaki, M.L. 1990. Endemism centres, refugia and botanical collection density in Brazilian Amazonia. Nature 345: 714-716.

O'Gorman, E. 1972. The invention of America: An inquiry into the historical nature of the New World and the meaning of its history. Westport, Connecticut: Greenwood Press.

Pagel, M. \& Meade, A. 2006. Bayesian analysis of correlated evolution of discrete characters by reversible-jump Markov chain Monte Carlo. Amer. Naturalist 167: 808-825.

Paradis, E., Claude, J. \& Strimmer, K. 2004. APE: Analyses of phylogenetics and evolution in R language. Bioinformatics 20: 289-290.

Pennington, R.T. \& Dick, C.W. 2004. The role of immigrants in the assembly of the South American rainforest tree flora. Philos. Trans., Ser. B 359: 1611-1622.

Pennington, R. \& Dick, C. 2010. Diversification of the Amazonian flora and its relation to key geological and environmental events: A molecular perspective. Pp. 373-385 in: Hoorn, C. \& Wesselingh, F. (eds.), Amazonia, landscape and species evolution, 1st ed. Oxford: Wiley-Blackwell.

Pennington, R.T., Lavin, M. \& Oliveira-Filho, A. 2009. Woody plant diversity, evolution, and ecology in the tropics: Perspectives from seasonally dry tropical forests. Annual Rev. Ecol. Syst. 40: 437-457.

Pennington, R.T., Lavin, M., Särkinen, T., Lewis, G.P., Klitgaard, B.B. \& Hughes, C.E. 2010. Contrasting plant diversification histories within the Andean biodiversity hotspot. Proc. Natl. Acad. Sci. U.S.A. 107: 13783-13787.

Pennington, R.T., Richardson, J.E. \& Lavin, M. 2006. Insights into the historical construction of species-rich biomes from dated plant phylogenies, neutral ecological theory and phylogenetic community structure. New Phytol. 172: 605-616.

Perret, M., Chautems, A. \& Spichiger, R. 2006. Dispersal-vicariance analyses in the tribe Sinningeae (Gesneriaceae): A clue to understanding biogeographical history of the Brazilian Atlantic forest. Ann. Missouri Bot. Gard. 93: 340-358.

Pirie, M.D., Chatrou, L.W., Mols, J.B., Erkens, R.H.J. \& Oosterhof, J. 2006. 'Andean-centred' genera in the short-branch clade of Annonaceae: Testing biogeographical hypotheses using phylogeny reconstruction and molecular dating. J. Biogeogr. 33: 31-46. 
Prance, G.T. 1973. Phytogeographic support for the theory of Pleistocene forest refuges in the Amazon basin, based on evidence from distribution patterns in Caryocaraceae, Chrysobalanaceae, Dichapetalaceae and Lecythidaceae. Acta Amazon. 3: 5-28.

Prance, G.T. 1978. The origin and evolution of the Amazon flora. Interciencia 3: 207-222.

Prance, G.T. 1982. A review of the phytogeographic evidences for Pleistocene climate changes in the Neotropics. Ann. Missouri Bot. Gard. 69: 594-624.

Queiroz, A. 2005. The resurrection of oceanic dispersal in historical biogeography. Trends Ecol. Evol. 20: 68-73.

Rabosky, D.L. 2010. Extinction rates should not be estimated from molecular phylogenies. Evolution 64: 1816-1824.

Rahbek, C. \& Graves, G.R. 2001. Multiscale assessment of patterns of avian species richness. Proc. Natl. Acad. Sci. U.S.A. 98: 4534-4539.

Ree, R.H. 2005. Detecting the historical signature of key innovations using stochastic models of character evolution and cladogenesis. Evolution 59: 257-265.

Renner, S.S. 2004. Plant dispersal across the tropical Atlantic by wind and sea currents. Int. J. Pl. Sci. 165

Renner, S.S. 2005. Relaxed molecular clocks for dating historical plant dispersal events. Trends Pl. Sci. 10: 550-558.

Richardson, J.E., Pennington, R.T., Pennington, T.D. \& Hollingsworth, P.M. 2001. Rapid diversification of a species-rich genus of neotropical rain forest trees. Science 293: 2242-2245.

Ricklefs, R.E. 2007. Estimating diversification rates from phylogenetic information. Trends Ecol. Evol. 22: 601-610.

Ricklefs, R.E. 2010. Evolutionary diversification, coevolution between populations and their antagonists, and the filling of niche space. Proc. Natl. Acad. Sci. U.S.A. 107: 1265-1272.

Rull, V.2005. Biotic diversification in the Guayana Highlands: A proposal. J. Biogeogr. 32: 921-927.

Rull, V. 2011. Origins of biodiversity. Science 331: 398-399.

Salati, E. \& Vose, P.B. 1984. Amazon basin: A system in equilibrium. Science 225: 129-138.

Santos, J.C., Coloma, L.A., Summers, K., Caldwell, J.P., Ree, R. \& Cannatella, D.C. 2009. Amazonian amphibian diversity is primarily derived from Late Miocene Andean lineages. PLoS Biol. 7: e1000056. DOI: 10.1371/journal.pbio.1000056.

Schultz, J. 2005. The ecozones of the world: The ecological divisions of the geosphere. Berlin: Springer.

Scotese, C.R. 2001. Atlas of Earth history. Arlington: PALEOMAP Project.

Sepulchre, P., Ramstein, G., Fluteau, F., Schuster, M., Tiercelin, J.J. \& Brunet, M. 2006. Tectonic uplift and Eastern Africa aridification. Science 313: 1419-1423.

Simon, M.F., Grether, R., de Queiroz, L.P., Skema, C., Pennington, R.T. \& Hughes, C.E. 2009. Recent assembly of the Cerrado, a neotropical plant diversity hotspot, by in situ evolution of adaptations to fire. Proc. Natl. Acad. Sci. U.S.A. 106: 20359-20364.

Simpson, G.G. 1980. Splendid isolation: The curious history of South American mammals. New Haven: Yale University Press.

Sklenář, P., Dušková, E. \& Balslev, H. In press. Tropical and Temperate: Evolutionary history of páramo flora. Bot. Rev. DOI: 10.1007/ s12229-010-9061-9.

Smith, B.T. \& Klicka, J. 2010. The profound influence of the Late Pliocene Panamanian uplift on the exchange, diversification, and distribution of New World birds. Ecography 33: 333-342.

Smith, M.A., Rodriguez, J.J., Whitfield, J.B., Deans, A.R., Janzen, D.H., Hallwachs, W. \& Hebert, P.D.N. 2008. Extreme diversity of tropical parasitoid wasps exposed by iterative integration of natural history, DNA barcoding, morphology, and collections. Proc. Natl. Acad. Sci. U.S.A. 105: 12359-12364.

Smith, S.A. 2009. Taking into account phylogenetic and divergencetime uncertainty in a parametric biogeographical analysis of the Northern Hemisphere plant clade Caprifolieae. J. Biogeogr. 36: 2324-2337.
Smith, T.B., Wayne, R.K., Girman, D.J. \& Bruford, M.W. 1997. A role for ecotones in generating rainforest biodiversity. Science 276: $1855-1857$.

Sparre, B. \& Andersson, L. 1991. A taxonomic revision of the Tropaeolaceae. Opera Bot. 108: 1-139.

Stebbins, G.L. 1974. Flowering plants: Evolution above the species level. London: Harvard University Press.

Stehli, F.G. \& Webb, S.D. 1985. The great American biotic interchange. New York: Plenum Press.

Svenning, J.C., Borchsenius, F., Bjorholm, S. \& Balslev, H. 2008. High tropical net diversification drives the New World latitudinal gradient in palm (Arecaceae) species richness. J. Biogeogr. 35: 394-406.

Svenning, J.C. \& Condit, R. 2008. Biodiversity in a warmer world. Science 322: 206-207.

Thomas, W.W. 1999. Conservation and monographic research on the flora of Tropical America. Biodivers. \& Conservation 8: 10071015.

Tripp, E.A. \& Manos, P.S. 2008. Is floral specialization an evolutionary dead-end? Pollination system transitions in Ruellia (Acanthaceae). Evolution 62: 1712-1737.

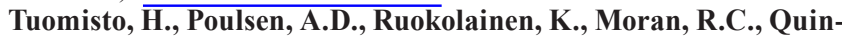
tana, C., Celi, J. \& Cañas, G. 2003a. Linking floristic patterns with soil heterogeneity and satellite imagery in Ecuadorian Amazonia. Ecol. Applic. 13: 352-371.

Tuomisto, H., Ruokolainen, K., Kalliola, R., Linna, A., Danjoy, W. \& Rodriguez, Z. 1995. Dissecting Amazonian biodiversity. Science 269: 63-66.

Tuomisto, H., Ruokolainen, K. \& Yli-Halla, M. 2003b. Dispersal, environment, and floristic variation of Western Amazonian forests. Science 299: 241-244

Valencia, R., Balslev, H. \& Paz y Mino, C.G. 1994. High tree alpha-diversity in Amazonian Ecuador. Biodivers. \& Conservation 3: 21-28.

Van der Cingel, N.A. \& Van der Cingel, N. 2001. An atlas of orchid pollination: America, Africa, Asia and Australia. Rotterdam: Balkema.

Wallace, A.R. 1852. On the monkeys of the Amazon. Proc. Zool. Soc. London 20: 107-110.

Wallace, A.R. 1853. A narrative of travels on the Amazon and Rio Negro. New York: Dover Edition.

Wallace, A.R. 1878. Tropical nature, and other essays. New York: Macmillan

Weigend, M. 2002. Observations on the biogeography of the AmotapeHuancabamba Zone in northern Peru. Bot. Rev. 68: 38-54.

Weigend, M. 2004. Additional observations on the biogeography of the Amotape-Huancabamba Zone in northern Peru-Defining the south-eastern limits. Revista Peruana Biol. 11: 127-134.

Weir, J.T., Bermingham, E. \& Schluter, D. 2009. The Great American Biotic Interchange in birds. Proc. Natl. Acad. Sci. U.S.A. 106: 21737-21742.

Wesselingh, F.P., Hoorn, C., Kroonenberg, S.B., Antonelli, A., Lundberg, J.G., Vonhof, H.B. \& Hooghiemstra, H. 2010. On the origin of Amazonian landscapes and biodiversity: A synthesis. Pp. 421-431 in: Hoorn, C. \& Wesselingh, F. (eds.), Amazonia: Landscape and species evolution, 1st ed. Oxford: Wiley-Blackwell.

Wesselingh, F.P., Räsänen, M.E., Irion, G., Vonhof, H.B., Kaandorp, R., Renema, W., Romero Pittman, L. \& Gingras, M. 2002. Lake Pebas: A palaeoecological reconstruction of a Miocene, long-lived lake complex in western Amazonia. Cainozoic Res. 1: 35-81.

Wiens, J.J. 2007. Global patterns of diversification and species richness in amphibians. Amer. Naturalist 170(Suppl.): 86-106.

Wiens, J.J. \& Donoghue, M.J. 2004. Historical biogeography, ecology and species richness. Trends Ecol. Evol. 19: 639-644.

Yesson, C. \& Culham, A. 2006. Phyloclimatic modeling: Combining phylogenetics and bioclimatic modeling. Syst. Biol. 55: 785-802.

Zachos, J., Pagani, M., Sloan, L., Thomas, E. \& Billups, K. 2001. Trends, rhythms, and aberrations in global climate 65 Ma to present. Science 292: 686-693. 